\title{
Extraction and characterization of ethanolic leaf extracts from Borreria hispida for cytotoxicity applications.
}

\author{
Chandrika $\mathbf{M}^{1,2}$, Chellaram $\mathrm{C}^{3 *}$ \\ ${ }^{1}$ Sathyabama Institute of Science and Technology, Chennai, Tamilnadu, India \\ ${ }^{2}$ Vel Tech Multitech, Dr. Rangarajan and Dr. Sakunthala Engineering College, Chennai, Tamilnadu, India \\ ${ }^{3}$ Sur College of Applied Sciences, Ministry of Applied Sciences, Sur-411, Sultanate of Oman
}

\begin{abstract}
The ethanolic leaf extract was collected from Borreria hispida using five different solvents by using shindai technique. The leaf extract contained total phenol and flavonoids with $33.21 \pm 0.6 \mathrm{mg}$ GAE and $18.27 \pm 0.08 \mathrm{mg} \mathrm{QE} / \mathrm{g}$, respectively which is crucial for the potential anticancer activity. The anti-oxidant and anticancer activity was performed by DPPH assay and MTT assay, respectively. The ethanolic leaf extract showed significant amount of phytochemicals with highest $(81.3 \pm 0.1 \%)$ radical scavenging activity. The most potent anticancer activity of ethanolic leaf extract was observed with an IC50 value of $150 \mu \mathrm{g} / \mathrm{ml}$. Cytotoxicity behaviour of ethanolic leaf extract against Hep cell line were demonstrated elaborately.
\end{abstract}

Keywords: Phenols, Cytotoxicity, Antioxidant, MTT assay, IC50.

Accepted May 17, 2019

\section{Introduction}

Plants establish significant wellspring of medications for counteractive action and spread of wide scope of pathogenic bearers and furthermore treating different infections of individuals. Current individuals progressively incline toward medications of characteristic inception generally from plant because of copious openness and less reactions. Though engineered medications and anti-microbial frequently cause wide spread danger and hurtful symptoms to the end client other than focused wellbeing condition pathogen bearer. Mixes segregated from plants are more secure and have a great deal of potential than the concoction drugs [1]. Customary home-grown medication is a rich hotspot for present day and atomic target explicit medication disclosure [2]. Plants have ended up being the most helpful in restoring sicknesses and give a significant wellspring of medication.

The medicinal importance of these plants lies in some chemical substances that produce a distinct physiological action on the body of human [3]. The major importance of these bioactive constitute in plants are Steroid, Terpenoids, Tannins, Carotenoids, Flavonoids, Alkaloids and Glycosides [4]. Medicinal plants are the foundation of many important drugs of the modern world. Plants based drug is the major area of research. According to WHO calculations, $80 \%$ of the world's population presently uses medicinal herbs drug for their primary health care [5-7]. Many plants are cheaper and more simply to get to the most people especially in the developing countries and these plants have lower incidence of side effects after use [8]. Synthetic drugs and antibiotics often cause wide spread toxicity and harmful side effects to the end user other than targeted health condition pathogen carrier. Compounds isolated from plants are safer and have a lot of potential than the chemical drugs [9-11]. Chemoprevention used to inhibit carcinogenesis to suppress the tumour. Current chemotherapeutic drugs are not useful in all cases and have severe side effects on human health. So there is increased demand in identification of new plant based drugs.

Borreria hispida L. has been extensively used in Siddha system of medicine for various conditions including decreasing the blood sugar levels. In traditional medicine, Spermacoce hispida is used to heal stomach ailments and also used as tonic and antidandruff. The flowers have been applied to boils, eruptions, swellings and also regarded as an emetic and as a remedy for coughs and malaria. The plant under study has been used since ages by folk because of its rich medicinal values. Spermacoce hispida Linn which is popularly known as "Nattaiccuri" in Tamil or "Shaggy button weed" in English belongs to family of Rubiaceae and the subfamily of Rubioideae, and the genus-Spermacoce. The whole plant is used for medicinal applications; it is widely available in the Western Ghats of Kerala and in Maruthamalai forest, which is an extension of Western Ghats in Tamil Nadu [7]. Also, B. hispida (Linn) and K. Schum. (Syn.: S. hispida $L$ ) is being used as an alternative therapy for diabetes [12]. In India, decoction of the plant is used for headache [13] and the seeds as stimulant [14] and for the treatment of internal injuries of nerves and kidney [15]. 


\section{Material and Methods}

\section{Materials}

Folin-Ciocalteau reagent, Aluminium chloride, Potassium acetate, Quercetin, Methanolic 1,1 diphenyl -2- picrylhydrazyl (DPPH), Butylated Hydroxy Toluene (BHT), phosphate buffered saline (PBS), MEM were received from Himedia. Fetal bovine serum (FBS) was purchased from Cistron laboratories. Trypsin, methylthiazolyl diphenyltetrazolium bromide (MTT), and Dimethyl sulfoxide (DMSO) were purchased from (Sisco research laboratory chemicals. Hep 2 (liver) cell lines were obtained from National centre for cell sciences Pune (NCCS). The medicinal plant Borreria hispida were collected from Thanjavur and Tirunelveli districts, Tamilnadu, India. The collected leaves were brought to the laboratory and maintained at Sathyabama University, Chennai, and Tamilnadu, India.

\section{Preparation of the plant extracts}

The plant extraction was prepared by the reported method [16]. The shade dried leaf (15 g each) of Borreria hispida were finely powdered with pestle and mortar and extracted with $150 \mathrm{ml}$ aqueous ethanol, chloroform, acetone and petroleum ether separately for 1 minute using an Ultra Turax mixer (13,000 RPM) and soaked overnight at room temperature. The sample was then filtered through whatman No.1 filter paper in a Buchner funnel. The filtered solution was evaporated under vacuum in a rotary evaporator $40^{\circ} \mathrm{C}$ to a constant weight and then dissolved in respective solvents. The concentrated extracts were stored with airtight container in refrigerator below $10^{\circ} \mathrm{C}$.

\section{Phytochemical screening for leaf extracts of Borreria hispida}

The powdered samples were tested for the presence of various phytochemicals. Plant extracts were taken with five different solvents such as acetone, ethanol, petroleum ether, chloroform and water. The plant extract was subjected for qualitative phytochemical screening for the presence of bioactive compounds terpenoids, alkaloids, glycosides and cardiac glycosides, steroids, quinines, coumarines, phenols, tannins, flavonoids, saponins, anthocyanin and betacyanin by the standard methods [17-19].

\section{Estimation of total phenol content}

The Folin - Ciocalteau reagent method was used for the estimation of total phenolic extracts quantities. Five concentrations of crude extracts of the plant was prepared and then $100 \mu \mathrm{L}$ taken from each concentration and mixed with $0.5 \mathrm{~mL}$ of Folin-Ciocalteau reagent (1/10 dilution) and $1.5 \mathrm{~mL}$ of $\mathrm{Na}_{2} \mathrm{CO}_{3} 2 \%(\mathrm{w} / \mathrm{v})$. The blend was incubated in the dark at room temperature for $15 \mathrm{~min}$. The absorbance of bluecolored solution of all samples was measured at $765 \mathrm{~nm}$. The results were expressed in gallic acid equivalent (GAE) per gram of dry weight of plant powders.

\section{Estimation of total flavonoid content}

Total flavonoids content in the ethanolic leaf extracts was determined by the aluminium chloride colorimetric method [20]. $0.5 \mathrm{ml}$ of leaf extracts of Borreria hispida at a concentration of $1 \mathrm{mg} / \mathrm{ml}$ were taken and the volume was made up to $3 \mathrm{ml}$ with methanol. Then $0.1 \mathrm{ml} \mathrm{AlCl}_{3}(10 \%)$, $0.1 \mathrm{ml}$ of potassium acetate and $2.8 \mathrm{ml}$ distilled water were added sequentially. The test solution was vigorously shaken. Absorbance was recorded at $415 \mathrm{~nm}$ after 30 minutes of incubation. A standard calibration plot was generated at $415 \mathrm{~nm}$ using known concentrations of quercetin. The concentrations of flavonoid in the test samples were calculated from the calibration plot and expressed as mg quercetin equivalent $/ \mathrm{g}$ of sample.

\section{Quantitative analysis of free radical scavenging activity of Borreria hispida}

The antioxidant activity was determined using DPPH, (SigmaAldrich) as a free radical. Sample extracts of $100 \mu$ l was mixed with $2.7 \mathrm{ml}$ of methanol and $200 \mu \mathrm{l}$ of $0.1 \%$ methanolic $\mathrm{DPPH}$. The suspension was incubated for 30 minutes in dark condition. Blank without the sample containing the same amount of methanol and DPPH solution was prepared and measured as control. Subsequently, at every 5 min interval, the absorption of the solution was measured using a UV double beam spectra scan (Chemito, India) at $517 \mathrm{~nm}$. The antioxidant activity of the sample was compared with known synthetic standard of $(0.16 \%)$ of Butylated Hydroxy Toluene (BHT). The experiment was carried out in triplicate; free radical scavenging activity was calculated by the following formula

$\%$ DPPH radical-scavenging $=$ (Absorbance of control Absorbance of test Sample)/(Absorbance of control) $] \times 100$

\section{In-vitro anticancer activity}

Cell line and culture: Hep 2 (liver) cell lines were obtained from National centre for cell sciences Pune (NCCS). The cells were maintained in Minimal Essential Media supplemented with 10\% FBS (Foetal Bovine Serum), penicillin (100 U/ml), and streptomycin $(100 \mu \mathrm{g} / \mathrm{ml})$ in a humidified atmosphere of $50 \mu \mathrm{g} / \mathrm{ml} \mathrm{CO}_{2}$ at $37^{\circ} \mathrm{C}$.

Principle of assay: This is a colorimetric assay that measures the reduction of yellow 3-(4, 5-dimethythiazol-2-yl)-2, 5-diphenyl tetrazolium bromide (MTT) by mitochondrial succinate dehydrogenase. The MTT enters the cells and passes into the mitochondria where it was reduced as an insoluble and coloured (dark purple) formazan product. The cells were then solubilized with an organic solvent (e.g. isopropanol) and then solubilized formazan reagent was measured spectrophotometrically.

In-vitro assay for cytotoxicity activity (MTT assay): The cytotoxicity of sample (Borreria hispida) on Hep G2 (liver) cell line was determined by the MTT assay [20]. Cells (1 $\times 10^{5} /$ well) were plated in $1 \mathrm{ml}$ of medium/well in 24-well plates (Costar Corning, Rochester, NY). Then, cells were incubated in the presence of various concentrations of the samples in $0.1 \%$ DMSO for $24 \mathrm{~h}$ at $37^{\circ} \mathrm{C}$. After removal of the sample solution and washing with phosphate-buffered saline 
(pH 7.4), $200 \mu \mathrm{l} /$ well $(5 \mathrm{mg} / \mathrm{ml})$ of $0.5 \%$ 3-(4, 5-dimethyl2-thiazolyl)-2, 5-diphenyl-tetrazolium bromide cells (MTT) phosphate -buffered saline solution was added. After $4 \mathrm{~h}$ incubation, $0.04 \mathrm{M} \mathrm{HCl} /$ isopropanol were added. Viable cells were determined by the absorbance at $570 \mathrm{~nm}$. Measurements were performed and the concentration required for a $50 \%$ inhibition of viability (IC50) was determined graphically. The absorbance at $570 \mathrm{~nm}$ was measured with a UVSpectrophotometer using wells without sample containing cells as blanks. The effect of the samples on the proliferation of Hep 2 (liver cell line) was expressed as the $\%$ cell viability, using the following formula:

$\%$ Cell viability $=\mathrm{A} 570$ of treated cells $/ \mathrm{A} 570$ of control cells $\times 100 \%$.

Anticancer activity against cancer cell lines: The cell lines of HeLa separately seeded in 96-well micro plates $\left(1 \times 10^{6}\right.$ cells/well) and incubated at $37^{\circ} \mathrm{C}$ for $24 \mathrm{~h}$ in $5 \% \mathrm{CO}_{2}$ incubator and allowed to grow $90 \%$ confluence. Then the medium was replaced and the cells were treated with and Borreria hispida at different concentration of such as 5, 10,25, 50, 75 and 100 $\mu \mathrm{g} / \mathrm{mL}$ and incubated for $24 \mathrm{~h}$. The cells were then washed with phosphate-buffer saline (PBS, pH-7.4) and $20 \mu \mathrm{L}$ of (MTT) solution $(5 \mathrm{mg} / \mathrm{mL})$ was added to each well. The plates were then stand at $37^{\circ} \mathrm{C}$ in the dark for additional $4 \mathrm{~h}$. The Formosan crystals were dissolved in $100 \mu \mathrm{L}$ DMSO and the absorbance was read spectrometrically at $570 \mathrm{~nm}$. The percentage of cell viability was expressed as above formula. The concentration that inhibited $50 \%$ of cell growth was referred as IC50 value, which was used as a parameter for cytotoxicity study. The morphological changes of untreated (control) and the cells treated at IC50 were observed under bright field microscope after $24 \mathrm{~h}$ and photographed.

\section{Assessment of apoptosis}

Propidium iodide (PI) nucleic acid stain: HeLa cell was separately plated at $5 \times 10^{4}$ cells/well into a six well chamber plate. At $>90 \%$ confluence, the cells were treated with Borreria hispida for $24 \mathrm{~h}$. The cells were washed with PBS fixed in methanol: acetic acid $(3: 1, \mathrm{v} / \mathrm{v})$ for $10 \mathrm{~min}$ and stained with $50 \mu \mathrm{g} / \mathrm{mL}$ propidium iodide (PI) for $20 \mathrm{~min}$.

Determination of cell death by Acridine orange (AO)/ Ethidium bromide (EB) dual staining: The HeLa cell was separately seeded in 6-well plates and treated with IC50 concentration of Borreria hispida for $24 \mathrm{~h}$ For the nuclear analysis, the monolayer of cells was washed with PBS and stained with $5 \mu \mathrm{L}$ of acridine orange $(100 \mu \mathrm{g} / \mathrm{mL})$ and $5 \mu \mathrm{L}$ of ethidium bromide $(100 \mu \mathrm{g} / \mathrm{mL})$. The morphological changes in the stained cells, the apoptotic nuclei (intensely stained, fragmented nuclei and condensed chromatin) were observed by fluorescent microscopy.

\section{Animals and treatment}

Male Wister rats of 16-19 weeks age, weighing 150-175 $\mathrm{g}$ were procured from the Central Animal House, Rajah Muthiah Medical College, Annamalai University. The animals were kept in cages, 2 per cage, with 12:12 hr light and dark cycle at $250 \pm 20^{\circ} \mathrm{C}$. The animals were maintained on their respective diets and water ad libitum. Animal Ethical Committee's clearance was obtained for the study. Animals were divided into following 6 Groups of 6 animals each.

Animal diet: The compositions of the two diets were as follows: Control diet: Wheat flour $22.5 \%$, roasted bengal gram powder $60 \%$, skimmed milk powder $5 \%$, casein $4 \%$, refined oil $4 \%$, salt mixture with starch $4 \%$ and vitamin \& choline mixture $0.5 \%$ [12].

High fat diet: Wheat flour $20.5 \%$, roasted Bengal gram $52.6 \%$, skimmed milk powder $5 \%$, casein $4 \%$, refined oil $4 \%$, coconut oil $9 \%$, salt mixture with starch $4 \%$ and vitamin \& choline mixture $0.5 \%$, cholesterol $0.4 \%$.

Rats of Groups III, IV and V were orally fed with the various extracts of Borreria hispida (pet. ether, ethyl acetate and ethanol) and rats of Group VI were fed with standard drug atorvastatin. Both the Borreria hispida extracts and atorvastatin were suspended in $2 \%$ tween 80 separately and fed to the respective rats by oral intubation.

At the end of 9 weeks all the animals were sacrificed by cervical decapitation after overnight fasting. Liver, heart and aorta were cleared of adhering fat, weighed accurately and used for the preparation of homogenate. Animals were given enough care as per the Animal Ethical Committee's recommendations. Portions of the tissues from liver, heart and aorta were blotted, weighed and homogenized with ethanol (3 volumes). The lipid extract obtained by the method of Folch et al. [13]. It was used for the estimation of thiobarbituric acid reactive substances 14 (TBARS).

Another portion of the tissues was homogenized with phosphate buffer saline and used for the estimation of reduced Glutathione [15] (GSH), Glutathione peroxidase [16] (GPx), Glutathione reductase [17] (GR), Catalase [18] (CAT), and Superoxide dismutase [19] (SOD).

Determination of proteins (T.P): This method is a combination of both Folin-ciocalteau and Biuret reaction which involves two step reactions. In the first Step Protein binds with copper in alkaline medium and reduces it to $\mathrm{Cu}^{++}$. In the second step $\mathrm{Cu}^{++}$formed catalyses the oxidation reaction of aromatic amino acid by reducing Phosphomolybdotungstate to heteropolymolybdanum, which leads to the formation of blue colour which is measured at $640 \mathrm{~nm}$.

Determination of superoxide dismutase (SOD): Superoxide dismutase scavenges the superoxide radical $\left(\mathrm{O}_{2}\right)$ and thus provides a first line defense against free radical damage. Superoxide dismutase is an endogenous enzymatic antioxidant which catalyzes the dismutation of superoxide free radical. This method is based on the inhibition of the

$$
2 \mathrm{H}_{2} \mathrm{O}+2 \mathrm{O}_{2}-\stackrel{\text { Superoxide dismutase }}{\longrightarrow} 2 \mathrm{H}_{2} \mathrm{O}_{2}+\mathrm{O}_{2}
$$

Superoxide anion $\left(\mathrm{O}_{2}-\right)$ interacts with peroxide to form hydroxyl radical $\left(\mathrm{OH}^{*}\right)$ which causes damage in the absence of superoxide dismutase activity $\left(\mathrm{R}^{*}\right)$

\section{Results and Discussion}

\section{FTIR studies}

FTIR spectra of different solvent extraction of Borreria 
hispida leaf are shown in Figures 1a-1d). Figure 1 (black color) shows the ethanol extraction of Borreria hispida highest peak intensity than other solvent extraction. The extracted Borreria hispida functional Groups and frequency region are given in the Tables 1 and 2.

\section{SEM analysis}

The SEM micrographs of the Borreria hispida (control) and ethanol extracted leaf Borreria hispida of are presented in Figures 2a-2d. The larger particles are formed by agglomeration, as predicted by morphological structure [20].

\section{Cytotoxicity behaviour against Vero and Hep $G_{2}$ cell lines using Borreria hispida}

Borreria hispida's are to be useful as anticancer drugs because of their stability, cytocompatibility, and flexible binding with biomolecules [21]. In recent times, the advancement of drugdelivery systems has been broadly attempted to produce the anticipated healing effect in patients with low opposing reactions [22]. In this work, the antiproliferative actions of Borreria hispida was examined in two different cancer cell lines (i.e., Vero, Hep G2 cells) and evaluated by MTT assay.

Observations of the effect of extracted Borreria hispida at different concentrations (i.e., $5,10,25,50,75$, and $100 \mu \mathrm{g} / \mathrm{ml}$ complexes) on cell viability of Vero, Hep G2 cells were made at $24 \mathrm{~h}$. The observed results explicated the cells' viability

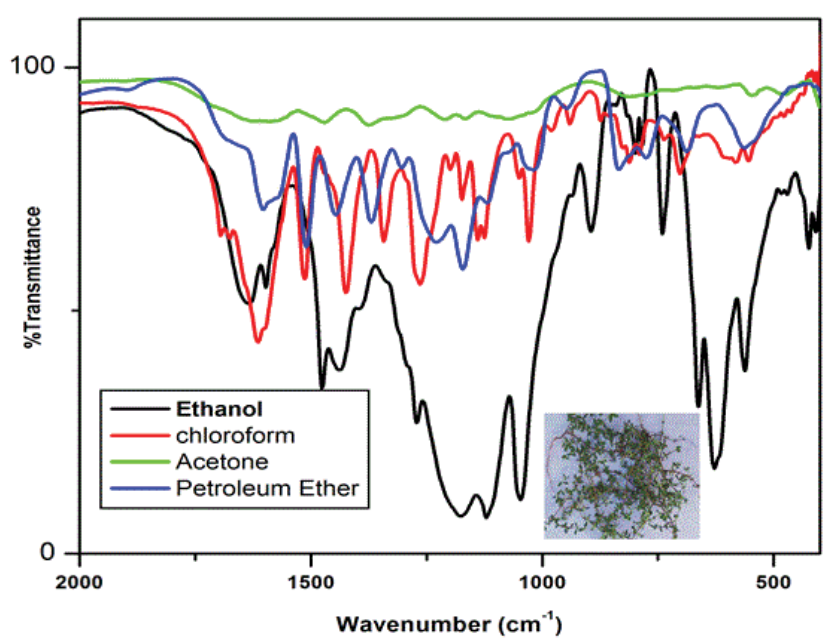

Figure 1. FTIR spectra of (a) ethanol (black), (b) chloroform (red), (c) acetone (green) and (d) petroleum ether (blue).

Table 1. The FTIR spectra of ethanol extraction of Borreria hispida.

\begin{tabular}{|c|c|c|}
\hline S. No & Frequency $\mathbf{~ c m}^{-\mathbf{1}}$ & Group Assigned \\
\hline 1 & 3482 & O-H stretching \\
\hline 2 & 3357 & O-H stretching \\
\hline 3 & 3289 & O-H stretching \\
\hline 4 & 2927 & SP3 C-H stretching \\
\hline 5 & 1604 & C=C double bond stretching \\
\hline 6 & 1461 & C-H bending \\
\hline 7 & 1373 & C-H bending \\
\hline 8 & 1101 & C-O stretching of alcohol \\
\hline 9 & 973 & C-H bending (Olefinic) \\
\hline 10 & 871 & C-H bending \\
\hline
\end{tabular}
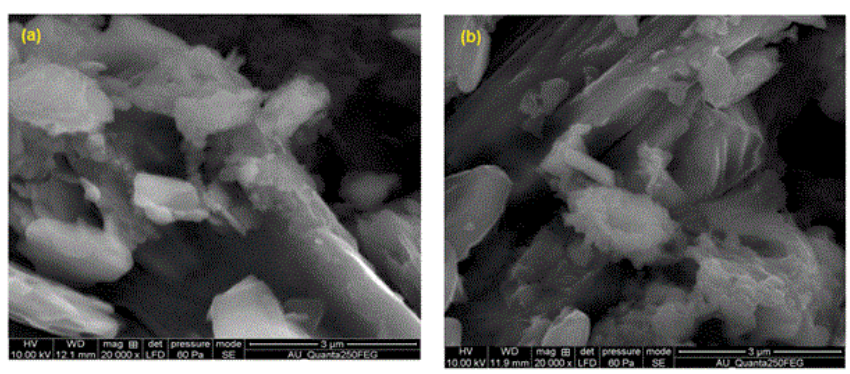

Figure 2. SEM images of (a) Borreria hispida (control) and (b) Borreria hispida ethanol extract.

at $85-90 \%$ for the concentrations Borreria hispida up to 5 $\mu \mathrm{g} / \mathrm{ml}$, as shown in Figures 3a-3f). As shown in Figure 3, efficiently induced apoptosis in Vero, Hep G2 cells in a dosage dependent manner. The Borreria hispida ethanol extracted leaf tested Vero cells displayed a good biocompatibility compared to the complex of other solvents, as shown in Figure 3. The effective decrements in cell viability were noted in treated concentrations when compared to control cells. An earlier report revealed that the Vero cell lines at higher metal complex concentrations exposed substantial cell death $[23,24]$.

The Vero cells treated for $24 \mathrm{~h}$ with the respective IC50 concentration of Borreria hispida became rounded and began to shrink and lose their interaction with nearby cells. The morphological images shown in Figure $3 \mathrm{~g}$ confirmed the toxic effect of Borreria hispida $(25 \mathrm{~g} / \mathrm{ml})$ samples against Vero cells compared with control cells.

\section{Morphological features of HepG2 cells stained with propidium iodide under fluorescence microscope}

The cytotoxic effect induced by ethanol extracted Borreria hispida involves apoptotic changes and nuclear condensation as demonstrated by the PI staining method. In control, HepG2 cells showed a very negligible number of PI positive cells. In the case of cells treated at IC50 of ethanol extracted Borreria hispida at $24 \mathrm{~h}$ showed a progressive increase in the number of propidium iodide positive cells (Figure 4). Similarly, Curcumin or catechin treated HCT15, HCT116 and HepG2 cell lines exhibited increased chromatin fluorescence, condensed nuclear morphology and presence of apoptotic bodies in the cancer cells [25]. In was suggested that nanoparticles can induce cell death in MCF7 cells through the reactive oxygen species mediated apoptotic process. The increased ROS levels and subsequent loss of mitochondria membrane potential might be the reason for increased apoptotic morphological changes in nanoparticles treated cells [26].

\section{Morphological features of HepG2 cells double stained with AO/EB under fluorescence microscopy}

Induction of apoptosis was analysed by detection of nuclear and cytoplasmic condensation with blebbing leading to the formation and release of apoptotic bodies. The detection and quantification of apoptosis and necrosis were also evaluated and compared by $\mathrm{AO} / \mathrm{EB}$ double staining for fluorescence microscopy $[27,28]$. This method combines the differential 

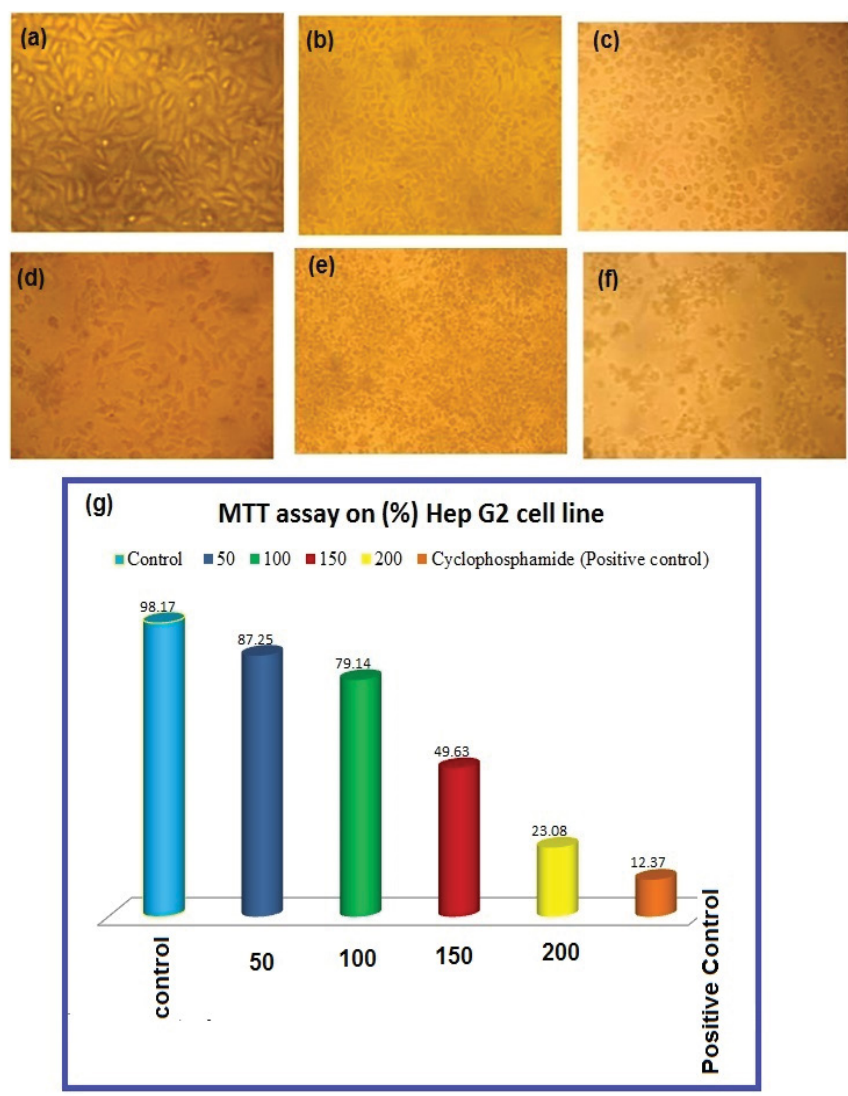

Figure 3. MTT assay on Hep G2 Cell line (Ethanolic leaf extract) a) Control cells (Untreated) b) Ethanolic leaf (Borreria hispida) extract $50 \mu \mathrm{g} / \mathrm{ml}$, c) Ethanolic leaf (B. hispida) extract $100 \mu \mathrm{g} /$ $\mathrm{ml}, \mathrm{d})$ : Ethanolic leaf (B. hispida) extract $150 \mu \mathrm{g} / \mathrm{ml}$ e) Ethanolic leaf (B. hispida) extract $200 \mu \mathrm{g} / \mathrm{ml}$ and f) Cyclophosphamide (Positive control) $80 \mu \mathrm{g} / \mathrm{ml}$.
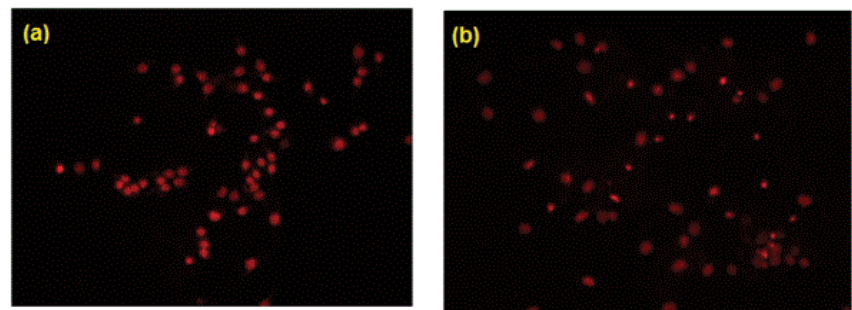

Figure 4. Morphological variation of PI-stained (a) Control (b) treated with Borreria hispida.

uptake of fluorescent DNA binding dyes of AO and EB and the allowing one to distinguish among viable, apoptotic, and necrotic cells. The AO is taken up by both viable and nonviable cells and emits either green fluorescence as a result of intercalation into double-stranded nucleic acids (mainly DNA), or red fluorescence as a result of binding to single-stranded nucleic acids (mainly RNA). The EB is taken up only by nonviable cells, and emits red fluorescence by intercalation into DNA. Thus, a viable cell possesses a uniform bright green nucleus and orange cytoplasm. An early apoptotic cell, whose membrane is still intact but has started to cleave its DNA, still has a green nucleus, but the chromatin of the cell becomes visible resulting from condensation in the form of bright green patches. A late apoptotic cell shows bright orange areas of condensed chromatin in the nucleus (EB predominates over AO), and a necrotic cell shows a uniform bright orange nucleus. In present study, HepG2 cells treated with IC50 concentration of AuNPs, after $24 \mathrm{~h}$, stained with $\mathrm{AO} / \mathrm{EB}$ fluorescence staining showed morphological apoptotic changes when compared to untreated control cells (Figure 5).

The control cells had shown uniform bright green nuclei and cytoplasm. Whereas the cells treated with AuNPs exhibited characteristic change of apoptosis i.e., cell shrinkage, nuclear condensation and fragmentation and formation of apoptotic bodies. They were observed as orange colored bodies. The necrotic cells were observed as red color fluorescence due to their loss of membrane integrity when viewed under fluorescence microscope [29,30] (Figures 6-8).

\section{In-vivo studies with statistical comparison}

Each Group $(n=6)$, each value represents Mean \pm SEM. One way ANOVA, followed by Dunnett comparison was performed. Control Group was compared with standard Group-II.

\section{Statistical Analysis}

Each Group $(n=6)$, each value represents Mean \pm SEM. One way ANOVA, followed by Dunnett comparison was performed. Control Group was compared with Std. Group-II. $\left({ }^{* * *} \mathrm{P}<0.001-{ }^{* *} \mathrm{P}<0.01,{ }^{*} \mathrm{P}<0.05\right)$ treated Groups III, IV and V was compared with Group I.

The concentration of tissues TBARS levels in HFD rats are shown in Table 3. Elevated levels of TBARS in liver,
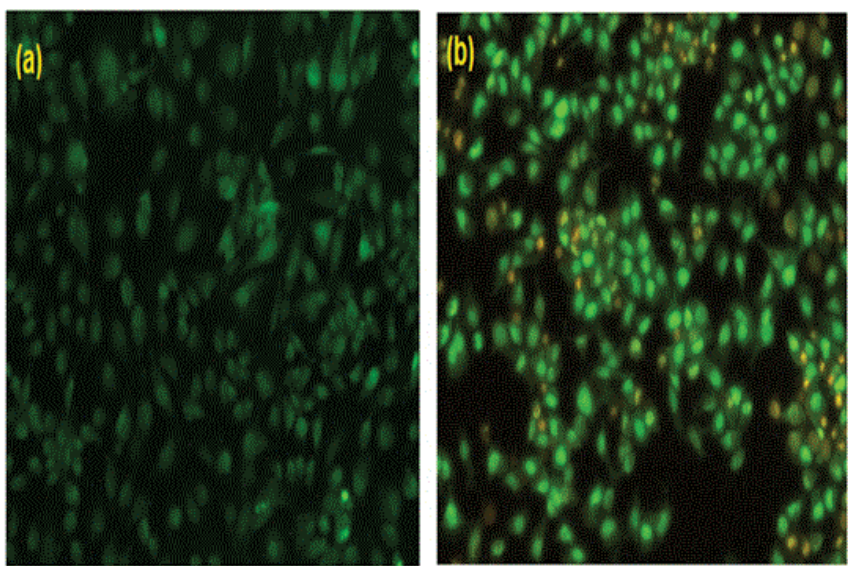

Figure 5. Morphological variation of $A O / E B$-stained (a) Control (b) treated with Borreria hispida.

\section{BODY WEIGHT}

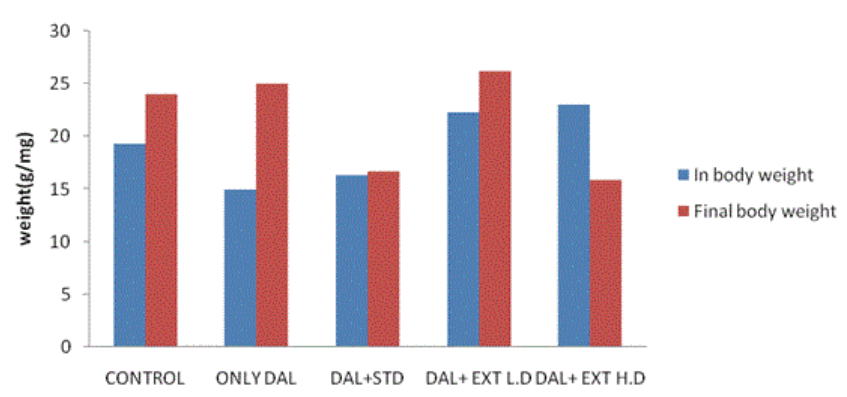

Figure 6. The in body weight and final body weight. 


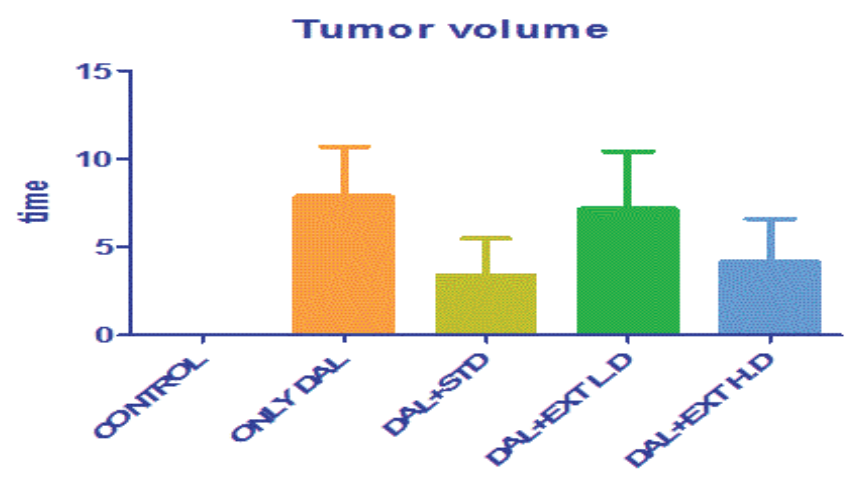

Figure 7. The volume of tumor.
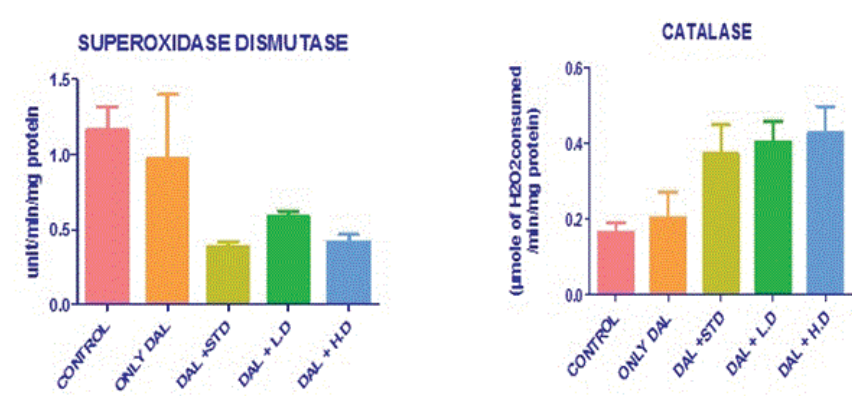

Figure 8. The SOD and CAT in tissue rats compared with other extracts.

heart and aorta in Group II rats are a clear manifestation of excessive formation of free radical and activation of lipid peroxidation. The significantly lowered the concentration of TBARS, in rats administered with methanolic extract of Borreria hispida along with HFD when compared with other two extracts.

Effect of various extracts of Borreria hispida on tissues Glutathione (GSH) content in rats fed HFD results. GSH also functions as free radical scavenger in the repair of radical caused biological damage [20]. The activities of glutathione concentration in tissues were significantly decreased in high fat diet rats (Group II) as compared to the control rats (Group I). Administration of methanolic extract of Borreria hispida along with HFD rats increased the levels of glutathione when compared with other two extracts.

Figure 8 shows that the effect of various extracts of Borreria hispida on tissues SOD and CAT enzyme levels in HFD rats. The activities of SOD and CAT in the tissue like liver, heart and aorta were significantly $(\mathrm{P}<0.001)$ lowered in rats fed with high fat diet (Group II) than control Group animals. High fat diet can cause the formation of toxic intermediates that can inhibit the activity of antioxidant enzyme and the accumulation of $\mathrm{O}_{2}-$ and $\mathrm{H}_{2} \mathrm{O}_{2}$ which in turn forms hydroxyl radicals. After administration of methanolic extract of Borreria hispida along with HFD significantly increases the activities of SOD and CAT in tissues of rats when compared with other extracts.

SOD was estimated as per the procedure described by Kakkar et al. [29]. Liver homogenate $(0.5 \mathrm{ml})$ was diluted with $0.5 \mathrm{ml}$ of distilled water. To this, $0.25 \mathrm{ml}$ ethanol and $0.15 \mathrm{ml}$ of chloroform, all reagents chilled, were added. The mixture was shaken for 1 minute and centrifuged at 2000 $\mathrm{rpm}$. The enzyme in the supernatant was determined. To $0.5 \mathrm{ml}$ of the supernatant, $1.5 \mathrm{ml}$ of buffer was added. The reaction was initiated by the addition of $0.4 \mathrm{ml}$ epinephrine and change in optical density per minute was measured at $480 \mathrm{~nm}$ in a double beam UV-VIS spectrophotometer (UV 1700, Szhimadzhu). SOD activity was expressed as U/mg. Change in optical density per minute at $50 \%$ inhibition to adrenochrome transition by the enzyme is taken as one enzyme unit (Figure 9).

Effect of various extracts of Borreria hispida on tissues glutathione perHoxidase (GPx) and glutathione reductase (GR) in HFD rats are shown in Figure 10. The effect of glutathione peroxidase and reductase was also significantly decreased in tissues of rats fed with HFD as compared to the control rats. High fat diet decreased the ratio of oxidized glutathione/ reduced glutathione in tissue [23]. Administration of methanolic extract Borreria hispida along with the HFD increased the activities of glutathione peroxidase and glutathione reductase in all the tissues as compared with HFD. A standard drug atorvastatin administered rats also showed elevated level of glutathione peroxidase and glutathione reductase.

Lowry method was adopted for the estimation of total protein [30]. Protein measurement with the Folin phenol reagent. To $0.1 \mathrm{ml}$ of the liver homogenate, $0.9 \mathrm{ml}$ of water, $4.5 \mathrm{ml}$ of alkaline copper sulphate reagent were added and allowed to stand in the room temperature for $10 \mathrm{~min}$. To this $0.5 \mathrm{ml}$ of Folin's reagent was added. After $20 \mathrm{~min}$, the blue colour developed was measured at $640 \mathrm{~nm}$. The level of protein present was expressed as $\mathrm{mg} / \mathrm{g}$ tissue or $\mathrm{mg} / \mathrm{dl}$.

\section{Histopathology}

Histopathology of different Group shown in Figures 11a-11d: Section studied from the liver shows preserved lobular architecture. Few foci show lympoplasmacytic infiltration with proliferation of thin walled vessels. Hepatocyte shows normal morphology. Portal tract shows normal. Contral vein shows mild dilatation. Sinusoids show dilatation Group-I (ONLY DAL). Group-II (DAL+5FU): Section studied from the liver shows maintained lobular architecture. Hepatocyte shows normal morphology. Portal tract shows normal. Contral vein and sinusoids shows mild dilatation. There is no evidence of inflammation/necrosis.

Group-V (DAL+EXT L.D.): Section studied from the liver shows preserved lobular architecture. Hepatocyte shows normal morphology. Portal tract shows lymphocytic infiltration. Contral vein shows normal. Sinusoids show mild dilatation.

Group-VI (DAL+EXT H.D.): Section studied from the liver shows sheets of atypical cells replacing the normal liver parenchyma. Individual cells are round to oval with moderate eosinophilic cytoplasm and round to oval vesicular nuclei with some showing nucleoli.1-2 mitosis/HPF noted. Other areas show normal hepatocytes and Portal vein and sinusoids. 
Table 2. The statistical comparison of in body weight and final body weight.

\begin{tabular}{|c|c|c|c|c|c|}
\hline Group & Control & Only DAL & DAL+STD & DAL+EXTL.D & DAL+EXT H.D \\
\hline In body weight & $19.3333 \pm 1.11555$ & $15 \pm 0.447214^{* * *}$ & $16.3333 \pm 0.614636^{*}$ & $22.3333 \pm 0.333333^{*}$ & $23 \pm 1^{* *}$ \\
\hline \multicolumn{2}{|l|}{$\left({ }^{* * *} \mathrm{P}<0.001{ }^{* * *} \mathrm{P}<0.01,{ }^{*} \mathrm{P}<0.05\right)$ treated Groups III, IV and V was compared with Group I } \\
\hline
\end{tabular}

Table 3. The statistical comparison of tumors.

\begin{tabular}{|c|c|c|c|c|c|}
\hline Group & Control & Only DAL & DAL+STD & DAL+EXTL.D & DAL+EXT H.D \\
\hline Tumor volume & $0 \pm 0$ & $7.86667 \pm 2.8378$ & $3.4 \pm 2.05913$ & $7.16667 \pm 3.24722$ & $4.18333 \pm 2.41391$ \\
\hline
\end{tabular}
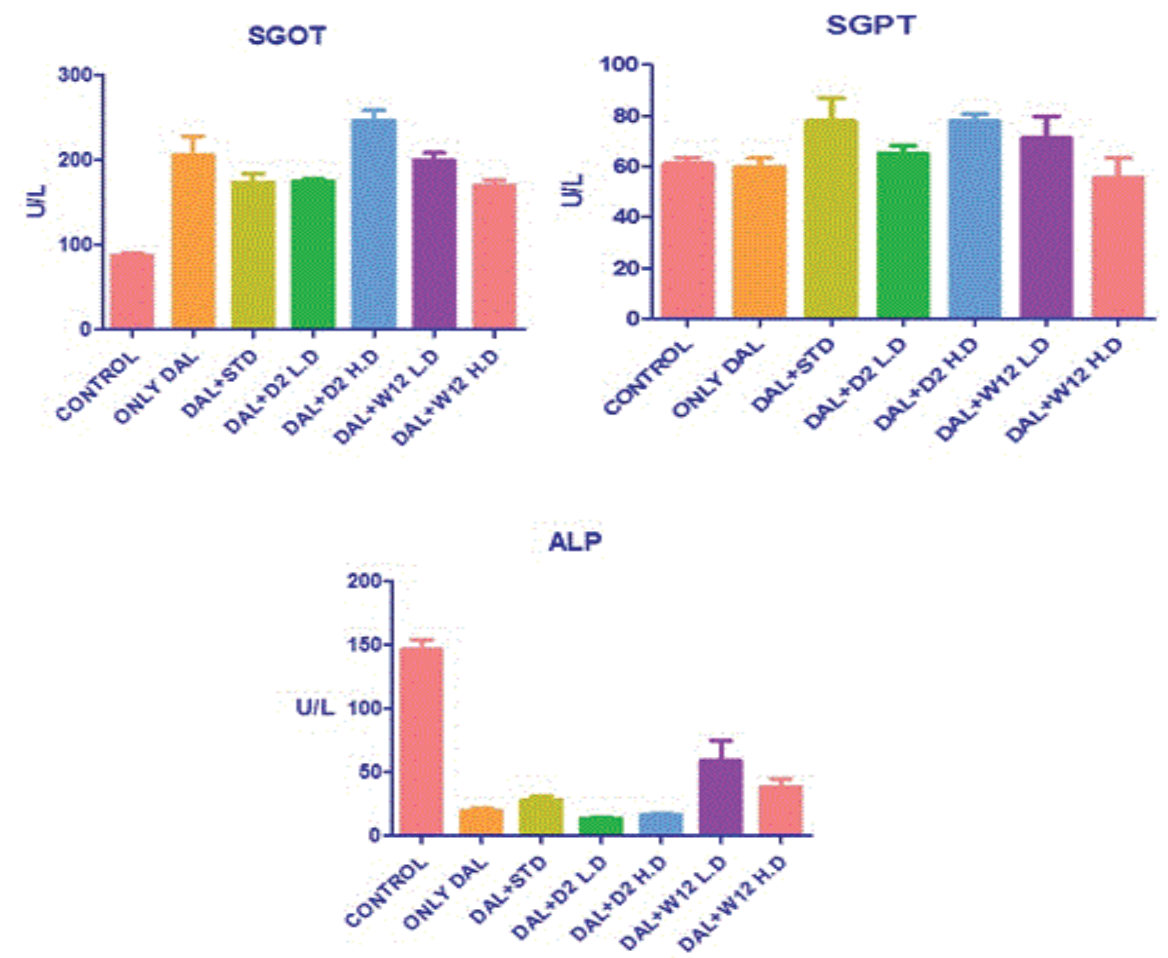

Figure 9. The SGOT, SGPT and ALP in tissue rats compared with other extracts.
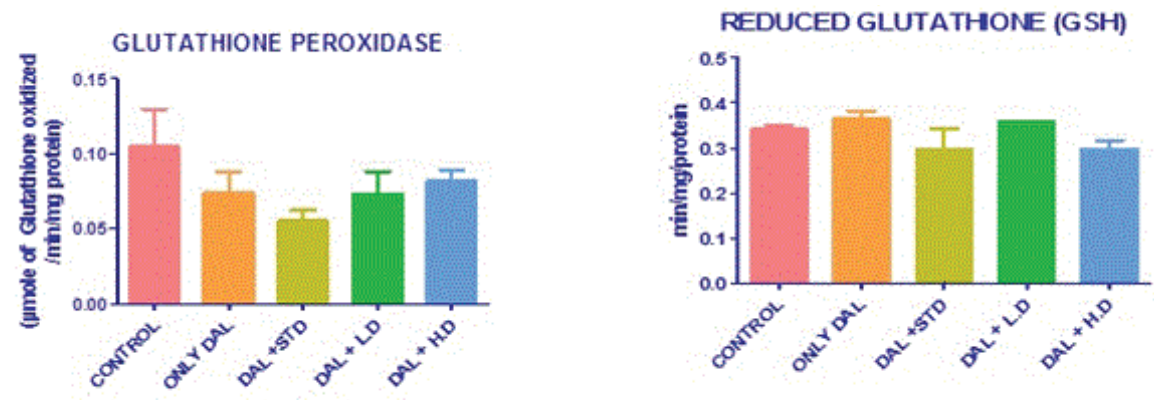

TOTAL PROTEIN

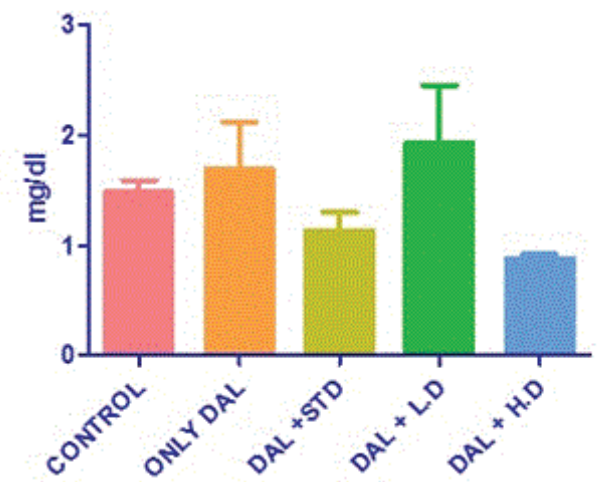

Figure 10. The GPx, GSH and Total protein in tissue rats compared with other extracts. 

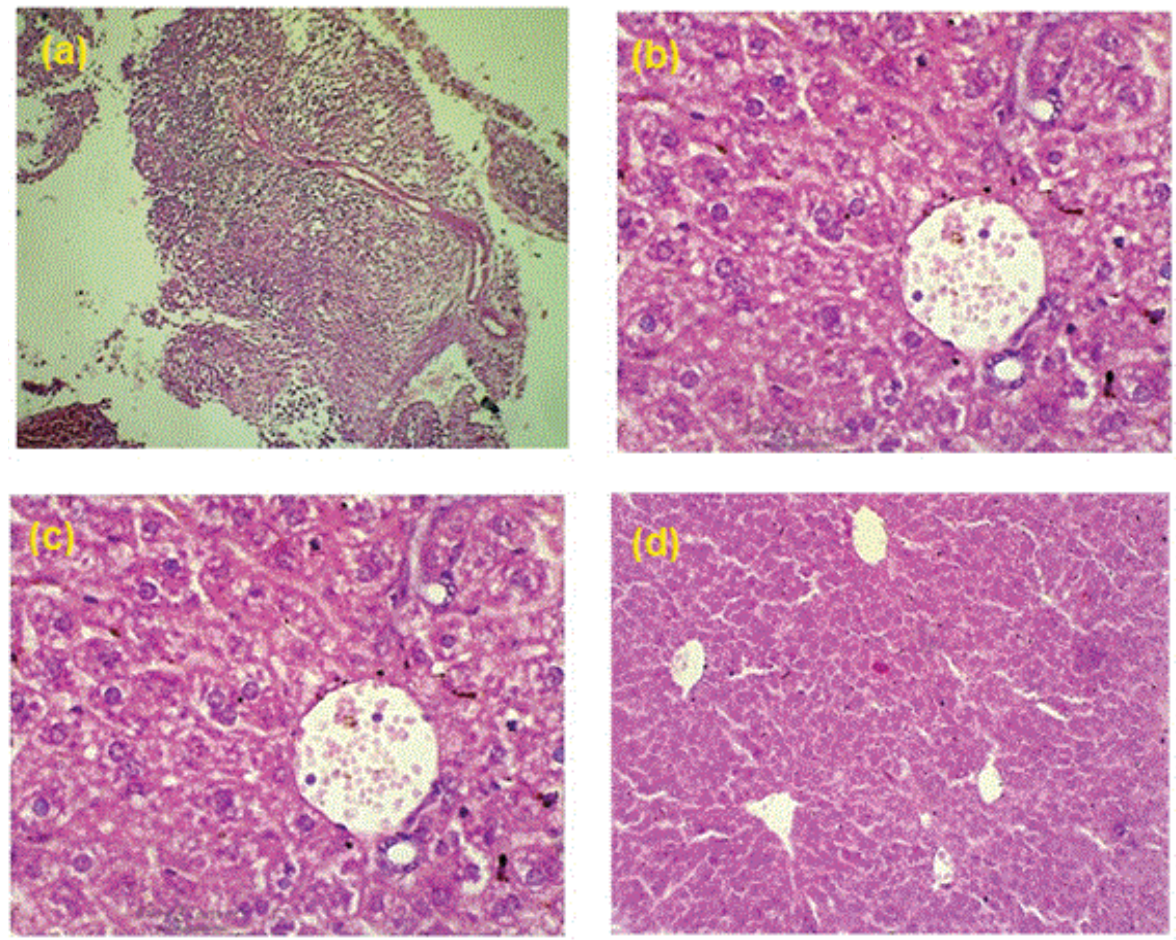

Figure 11. The (a) Only DAL, (b) DAL +5FU (c) DAL+EXT L.D. and (d) DAL+EXT H.D. in tissue rats compared with other extracts.

\section{Conclusion}

From the above findings it can be concluded that the ethanolic leaf extract of Borreria hispida possesses promising effect on anti-oxidant and anticancer activities. The presence of phenol and flavanoids in the ethanolic leaf extract of the plant under study may be responsible for their activities. It indicates that the plant material become an important source of natural drug compounds.

\section{Author Contributions}

MC initiated the study, performed the extensive experiments related to the growth of the samples and manuscript preparation with guidance by corresponding author Dr. CC and $\mathrm{CC}$ given his valuable suggestions include, planning, design experimental work, data analysis, discussion and manuscript preparation. Both authors' contributions are equal and both were read and approved the final manuscript.

\section{References}

1. Harborne AJ. Phytochemical methods a guide to modern techniques of plant analysis. 1998.

2. George B, Kaur C, Khurdiya DS, Kapper HC. (Lycopersicon esculentum) as a function of genotype. Food Chem 2004; 84: 45-51.

3. Balandrin NF, Kinghorn, AD. Human medicinal agents from plants: In: ACS Symposium Series. Chapter 1. 1993; pp. 2-12.

4. Engel LW, Straus SE. Development of therapeutics opportunities within complementary and alternative medicine. Nat Rev Drug Discov 2002; 1: 229-237.

5. Chellaram C, Raja P, Diraviya RK. Medicinal properties of green seaweeds, Ulva fasciata (Delile, 1813) and U. reticulate (Forsskal, 1777). Int J Res Pharma Sci, 2015; 6: 1-6.
6. Malar GR, Chellaram C. Alpha amylase and alpha glucosidase inhibitory effects of aqueous stem extract of Salacia oblonga and its GC-MS Analysis. Brazilian J Pharma Sci 2018; 54: 1-10.

7. Etkin, NL, Hausa A. Herbal Pharmacopoeia: Biomedical evaluation of commonly used plant medicines. J Ethnopharmacol 1981; 4: 75-98.

8. Wislson FEO. Biodiversity National Academy Press Washington, USA. 1998.

9. Greer J, Erickson, JW, Baldwin JJ, Varney MD. Application of the three-dimensional structures of protein target molecules in structure-based drug design. 2003, J. Med. Chem. 37:8, 10351054.

10. Priya G, Chellaram C. Anti-proliferative effect of ethanolic leaf extract of Solanum trilobatum on Hep2 Cancer Cell Lines. Asian J Pharma Clin Res. 2014; 7: 58-61.

11. Priya G, Chellaram C 2014. Phytochemical and therapeutic evaluation of leaf and in vitro derived callus and shoot of Solanum trilobatum L. Pakistan J Pharma Sci. 2014; 27: 21012107.

12. Greer J, Erickson JW, Baldwin JJ, Varney MD. Application of the three-dimensional structures of protein target molecules in structure-based drug design. J Med Chem. 1994; 37: 1035-1054.

13. Vasanthi HR, Mukherjee S, Lekli I, Ray D, Veeraraghavan G, Das DK. Potential role of Borreria hispida in ameliorating cardiovascular risk factors J Cardiovasc Pharmacol 2009; 53: 499-506

14. Khan SS, Chaghtai SA, Oommachan M. Medicinal plants of Rubiaceae of Bhopal - An Ethnobotanical study. J Scient Res (Bhopal) 1984;6:37-9.

15. Purushothaman KK, Kalyani K. Isolation of isorhamnetin from Borreria hispida Linn. J Res Indian Med Yoga Homeop. 1979;14: 131-132. 
16. Waynforth BH. Injection techniques experimental and surgical techniques in the rats. Academic Press, London, UK. 1980.

17. Pezzuto JM. Plant - derived anticancer agents. Biochem Pharmacol 1997; 53: 121-33.

18. Mosmann T. Rapid colorimetric assay for cellular growth and survival: Application to proliferation and cytotoxicity assays. J Immunol Methods 1983; 65: 55-63.

19. Kuz'min VE, Artemenko AG, Lozytska RN, Fedtchouk AS, Lozitsky VP, Muratov EN, Mescheriakov AK. Investigation of anticancer activity of macrocyclic Schiff bases by means of D-QSAR based on simplex representation of molecular structure. SAR QSAR Environ Res 2005; 16: 219-230.

20. El-halim AHF, Omar MM, Mohamed GG. Synthesis, structural, thermal studies and biological activity of a tridentate Schiff base ligand and their transition metal complexes. Spectrochim Acta A Mol Biomol Spectrosc 2011; 78: 36-44.

21. Ramade I, Kahn O, Jeannin Y, Robert F. Design and magnetic properties of a magnetically isolated GdIIICuII pair crystal structures of $[\mathrm{Gd}(\mathrm{hfa}) 3 \mathrm{Cu}($ salen $)], \quad[\mathrm{Y}(\mathrm{hfa}) 3 \mathrm{Cu}($ salen $)]$, $[\mathrm{Gd}(\mathrm{hfa}) 3 \mathrm{Cu}$ (salen)(Meim) $]$, and $\left[\mathrm{La}(\mathrm{hfa}) 3\left(\mathrm{H}_{2} \mathrm{O}\right) \mathrm{Cu}(\right.$ salen) $]$ $\left[\mathrm{hfa}=\right.$ Hexafluoroacetylacetonato, salen $=\mathrm{N}, \mathrm{N}^{2}$-Ethylenebis (salicylideneaminato), Meim=1-Methylimidazole]. Inorg Chem 1997; 36: 930-936.

22. Jayabalakrishnan C, Natarajan K. Ruthenium (II) carbonyl complexes with tridentate Schiff bases and their antibacterial activity. Transit Metal Chem 2002; 27: 75-79.

23. Ansary AL, Kader ANS. Synthesis, characterization of La (III),
$\mathrm{Nd}$ (III) and Er(III) complexes with Schiff bases derived from Benzopyran-4-one and thier fluorescence study. International Journal of Inorg Chem 2012; 12: 1-13.

24. Yan ZZ, Tang Y, Liu WS, Cui HX, Tan MY. Synthesis and luminescent properties of lanthanide complexes with a novel multipodal ligand. J Fluoresc 2008; 18: 473-478.

25. Sinha D, Tiwari AK, Singh S, Shukla G, Mishra P, Chandra H, Mishra AK. Synthesis, characterization and biological activity of Schiff base analogues of indole-3-carboxaldehyde. Eur J Med Chem 2008; 43: 160-165.

26. Adsule S, Barve V, Chen D, Ahmed F, Dou QP, Padhye S, Sarkar FH. Novel Schiff base copper complexes of quinoline-2 carboxaldehyde as proteasome inhibitors in human prostate cancer cells. J Med Chem 2006; 49: 7242-7246.

27. Trimukhe K, Varma A. Metal complexes of crosslinked chitosans: Correlations between metal ion complexation values and thermal properties. Carbohyd Polym 2009; 75:63-70.

28. Pavlovetc IM, Draguta S, Fokina MI, Timofeeva TV, Denisyuk IY. Synthesis, crystal growth, thermal and spectroscopic studies of acentric materials constructed from aminopyridines and 4-nitrophenol. Opt Commun 2016; 362: 64-68.

29. KakkarP, Das B, Viswanathan PN. A modified spectrophotometic assay of SOD, Ind J Biochem Biophy 1984; 21: 130-132.

30. Lowry OH, Rosebrough NJ, Farr AL, Randall RJ. Protein measurement with the Folin phenol reagent. J Biol Chem 1951; 193: 265-275.

\section{*Correspondence to}

Chellaram C,

Sur College of Applied Sciences,

Ministry of Applied Sciences,

Sur-411,

Sultanate of Oman. 